Рекомендована д. фрармац. наук, проф. Т. Г. Калинюком

УДК 615.454.1:546.3-022.513.2

DOI 10.11603/2312-0967.2018.3.9339

\title{
ВИБІР ОПТИМАЛЬНОГО СКЛАДУ КРЕМУ 3 НАНОЧАСТИНКАМИ ЦЕРІЮ дІокСиду
}

\author{
(СГ. В. Зайченко ${ }^{1}$, О. А. Покотилоㄹ, Д. В. Литкін ${ }^{2}$ \\ Національний медичний університет імені О. О. Богомольця ${ }^{1}$, Київ \\ Національний фрармацевтичний університет², Харків \\ oksana.pokotulo@gmail.com
}

\begin{abstract}
Мета роботи. Скринінгове дослідження активності тест-зразків кремів із наночастинками церію діоксиду (НЦД) на моделі фротодинамічного запалення в мурчаків із виявленням зразка-лідера з оптимальним вмістом НЦД у складі лікарської форми для подальшого поглибленого фрармакологічного вивчення крему.

Матеріали і методи. Стандартизовані НЦД розміром 6-15 нм синтезовані співробітниками ТОВ «НаноМедТех», тест-зразки кремів розроблені у НТК «Інститут монокристалів» НАН України. Фотодинамічну травму у мурчаків викликали УФ опромінюванням за допомогою ртутно-кварцової лампи. Креми наносили просрілактично дозою 2 мг/см². Ступінь вираженості еритеми - головного прояву запальної реакції - оцінювали за колориметричною шкалою С. В. Суворова у динаміці. За цим показником розраховували фротопротекторну активність (ФПА). Здатність кремів попереджати запальний процес визначали за зміною температури шкірних покривів, кількості лейкоцитів та вмісту гістаміну в крові мурчаків.

Результати й обговорення. За сукупністю досліджених показників крем із 0,25 \% НЦД виявив найвищу фармакологічну активність: ФПА була найбільшою серед усіх тест-зразків та становила 43,6 \%. Одноразове нанесення крему сприяло нормалізації температури шкіри та вмісту гістаміну у крові, кількість лейкоцитів була на 17,4 \% нижче, ніж у групі контрольної патології.

Висновки. За результатами скринінгових досліджень крем з 0,25 \% НЦД визнано зразком-лідером та рекомендовано як остаточний склад лікарської фрорми для подальшого поглибленого фрармакологічного вивчення.
\end{abstract}

Ключові слова: наночастинки церію діоксиду; фотопротекторна активність; фоотодинамічна травма; скринінг; мурчаки.

Вступ. Ультрафріолетове (УФ) ураження шкіри (фотодинамічна травма, чи сонячний опік) - поширена патологія, зустрічається практично у всіх групах населення. Ризик розвитку в будь-який час року обернено пропорційний ступеню пігментації шкіри, високий серед відвідувачів соляріїв, фрахівців, які працюють на відкритому повітрі на височинах, осіб, що страждають на певні дерматологічні захворювання чи контактують 3 фротосенсибілізуючими речовинами. Люди, які підлягають надмірному УФ опроміненню, схильні до розвитку меланоми, плоскоклітинного та базальноклітинного раку шкіри [1-3].

Для попередження УФ ураження шкіри та зниження ризику появи пов'язаних з цим злоякісних новоутворень на сьогодні застосовують фротопротектори. Поширення набули косметичні та лікарські засоби 3 «фізичними» фрільтрами, що включають такі неорганічні сполуки, як титану діоксид (ТД) і цинку оксид. Останні ефрективно відбивають та заломлюють УФ промені в небезпечних для організму діапазонах. Зазвичай дані сполуки безпечні, однак за рахунок часткового поглинання сонячної енергії можуть проявля- ти фротокаталітичні властивості, що є причиною ураження тканин [4, 5].

Як альтернативу зазначеним вище сполукам розглядають наночастинки церію діоксиду (НЦД), зокрема завдяки подвійному механізму фотопротекторної дії останніх. 3 одного боку, НЦД - це ефективний «фрізичний» фотопротектор - світлофрільтр, здатний вибірково диспергувати сонячне світло, відбиваючи та розсіюючи небезпечні УФ хвилі і пропускаючи світло видимого діапазону. 3 іншого боку, НЦД є сильними антиоксидантами, що є додатковим фрактором посилення ефективності даного активного фрармацевтичного інгредієнта (АФІ) як фротопротектора та вказує на відсутність фротокаталітичної активності. Безпеку НЦД доведено у попередніх токсикологічних дослідженнях in vitro та in vivo [6-8].

Важливим етапом розробки лікарського та косметичного засобу є проведення скринінгу задля визначення оптимальної дози АФІ, яка б забезпечувала належне співвідношення користь/ризик.

Мета роботи - скринінгове дослідження активності тест-зразків кремів із наночастинками церію діоксиду

ISSN 2312-0967. Pharmaceutical review. 2018. № 3 
Фармацевтична технологія, біофармація, гомеопатія Pharmaceutical technology, biopharmacy, homeopathy

(НЦД) на моделі фротодинамічного запалення у мурчаків із виявленням зразка-лідера з оптимальним вмістом НЦД у складі лікарської фрорми для подальшого поглибленого фрармакологічного вивчення крему.

Матеріали і методи. Стандартизовані НЦД розміром 6-15 нм синтезовані співробітниками ТОВ «НаноМедТех» (м. Київ), тест-зразки дермальних кремів розроблені у НТК "Інститут монокристалів" НАН України (м. Харків), містили наступні допоміжні речовини: діетиламіногідроксибензоїлгексилбензоат (Uvinul A Plus), етилгексилметоксицинамат (Uvinul MC 80), біс-етилгексилоксифенолметоксифенілтріаз ин (Tinosorb S), метилен біс-бензотріазолілтетрамети лбутилфенол (Tinosorb M), френоксиетанол, етилгексилгліцерин, дібутиладипат, С12-15 алкілбензоат, макроголу 20 цетостеариловий ефрір, цетостеариловий спирт, циклометикон, динатрію едетат, ксантанова камедь, пропіленгліколь, вода очищена. Порівняльний склад тест-зразків кремів наведено в таблиці 1.

Фотопротекторну активність кремів вивчали на моделі фоотодинамічної травми у мурчаків [9] - гострого фотодинамічного запалення шкіри (УФ еритеми), яке викликали за допомогою УФ опромінювача типу ОКН-011М (Завет, Україна). Діапазон опромінення становив 220-400 нм. Ефективність кремів з НЦД порівнювали 3 рефрерентним зразком - кремом, який містив 3 \% титану діоксиду, ч.д.а., виробництва Sigma-Aldrich (ТД) як АФІ, а також 3 кремовою основою.

Експеримент проводили на 70 нелінійних мурчаках (Cavia porcellus) обох статей, масою 450-500 г, розподілених на 7 груп (по 10 тварин у кожній): група 1 - контрольні здорові інтактні тварини - інтактний контроль, група 2 -опромінені тварини - контрольна патологія (УФ), група 3 - тварини, яким перед опроміненням наносили крем НЦД 0,1\% (НЦД 0,1\%+ УФ), група 4 - тварини, яким перед опроміненням наносили крем НЦД 0,25 \% (НЦД 0,25 \% + УФ), група 5 - тварини, яким перед опроміненням наносили крем НЦД 0,5 \% (НЦД 0,5 \% + УФ), група 6 - тварини, яким перед опроміненням наносили крем ТД $3 \%$ - референтний зразок (ТД $3 \%+$ УФ), група 7 - тварини, яким перед опроміненням наносили кремову основу (плацебо + УФ).

Дослідження виконано із дотриманням положень Директиви Європейського парламенту та Ради ЄС 2010/63/ЄС від 22.09.2010 р. про захист тварин, які використовуються для наукових цілей. Мурчаків виводили з експерименту під хлороформним наркозом через 24 год після опромінення.

Перед початком досліду всім тваринам проводили депіляцію на ділянці спини, яку умовно поділяли за допомогою трафрарету на три «вікна», площа кожного з яких становила 3 см² $^{2}$

Джерело УФ випромінювання розміщували на відстані 10 см від поверхні шкіри тварини, час опромінення становив 3 хв та відповідав 5 МЕД (мінімальним еритемним дозам).

Креми наносили в профрілактичному режимі на депільовані ділянки шкіри тварин за 20 хв до опромі-

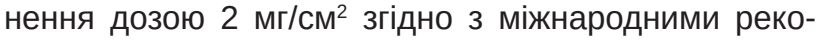
мендаціями [4]. Таким чином, мурчаки з груп 3, 4 і 5 отримували нашкірно дозу НЦД 0,04, 0,1 і 0,2 мг/кг, відповідно.

Оцінку ступеня вираженості еритеми проводили через 1, 2, 4, 8, 16 та 24 год після опромінення і фріксували в балах за колориметричною шкалою С. В. Суворова: 0 - відсутність еритеми, 1 - слабка еритема (рожевий тон), 2 - помірно виражена еритема (рожево-червоний тон), 3 - виражена еритема (червоний тон), 4 - різко виражена еритема (яскраво-червоний тон). За значення показника у кожної тварини приймали середнє арифрметичне ступеня вираженості еритеми, виміряного у трьох вікнах [10].

Фотопротекторну активність (ФПА) кремів розраховували за орормулою 1 :

$$
\text { ФПА = }\left(\mathrm{E}_{\mathrm{ко}}-\mathrm{E}_{\mathrm{кр}}\right) \times 100 / \mathrm{E}_{\mathrm{ко}}, \text { (1) }
$$

де $\mathrm{E}_{\text {кр }}$ - ступінь вираженості еритеми (в балах) на ділянці шкіри, де було нанесено крем (групи 3-7), через 24 год після опромінення;

$\mathrm{E}_{\text {ко }}$ - ступінь вираженості еритеми (в балах) на ділянці шкіри, яка підлягала УФ опроміненню (група 2 - контрольна патологія), через 24 год після опромінення.

Таблиця 1. Склад тест-зразків кремів, що піддавалися скринінговому дослідженню фотопротекторної активності (у г на 100 г)

\begin{tabular}{|c|c|c|c|c|c|}
\hline \multirow{3}{*}{ Компоненти } & \multicolumn{5}{|c|}{ Тест-зразки кремів } \\
\hline & \multicolumn{3}{|c|}{ НЦД } & \multirow{2}{*}{$\begin{array}{c}\text { ТД } 3 \text { \% } \\
\text { (ресрерентний зразок) }\end{array}$} & \multirow{2}{*}{$\begin{array}{c}\text { Плацебо (кремова } \\
\text { основа) }\end{array}$} \\
\hline & $0,1 \%$ & $0,25 \%$ & $0,5 \%$ & & \\
\hline НЦД & 0,1 & 0,25 & 0,5 & - & - \\
\hline ТД & - & - & - & 3,0 & - \\
\hline Uvinul A Plus & 5,0 & 5,0 & 5,0 & 5,0 & 5,0 \\
\hline Uvinul MC 80 & 10,0 & 10,0 & 10,0 & 10,0 & 10,0 \\
\hline Tinosorb S & 2,0 & 2,0 & 2,0 & 2,0 & 2,0 \\
\hline Tinosorb M & 2,0 & 2,0 & 2,0 & 2,0 & 2,0 \\
\hline
\end{tabular}

ISSN 2312-0967. Фармацевтичний часопис. 2018. № 3 
Для оцінки ступеня УФ ушкодження тканин та здатності кремів попереджати розвиток запалення протягом 4 год після опромінення визначали температуру шкірних покривів [11], що є інтегральним показником активності запального процесу та маркером васкулярних змін дерми при даній патології. Підвищення температури проявляється за рахунок вивільнення прозапальних і таких вазоактивних медіаторів, як гістамін, серотонін, брадикінін, простагландини та інтерлейкіни $[12,13]$. Вимірювання температури шкірної складки тварин проводили за допомогою термометра MT1931 (Microlife, Швейцарія).

Перебіг патологічного процесу також оцінювали за наявністю лейкоцитозу як гематологічного маркера системної запальної реакції на УФ опромінення. Забір крові проводили з вушних капілярів мурчаків безпосередньо перед дослідом та через 24 год від початку експерименту. Кількість лейкоцитів підраховували у камері Горяєва [11].

Пошкодження тканин шкіри УФ опроміненням супроводжується дегрануляцією опасистих клітин та виходом гістаміну - медіатора ранньої фрази запалення [14]. Вміст даного маркера запалення в крові 3 вушних капілярів тварин визначали методом світлової колориметрії через одну год після опромінення. Принцип методу заснований на утворенні забарвленого комплексу гістаміну 3 діазотованим п-нітроаніліном [15].

Статистичну обробку даних здійснювали за допомогою програми IBM SPSS Statistics v.23 (IBM, США), з використанням однофакторного дисперсійного аналізу ANOVA 3 post-hoc порівняннями із застосуванням HSD-критерію Тьюкі (температура шкірних покривів, кількість лейкоцитів та вміст гістаміну в крові),
Фармацевтична технологія, біофармація, гомеопатія Pharmaceutical technology, biopharmacy, homeopathy

парного двовибіркового t-тесту для середніх (динаміка зміни температури шкірних покривів) та Н-критерію Крускала-Уолліса 3 post-hoc порівняннями із застосуванням критерію Данна (ступінь вираженості еритеми). Відмінності показників вважали статистично значущими при $\mathrm{p}<0,05$.

Результати й обговорення. Протягом експерименту динаміку розвитку фротодинамічної травми у мурчаків оцінювали за ступенем вираженості еритеми (табл. 2). У групі контрольної патології спостерігали зростання показника протягом всього періоду спостереження (24 год). У даних мурчаків виявляли ділянки особливо сильної еритеми та виразок на шкірі.

Схожу картину спостерігали у групі нанесення плацебо. Лише через 24 год після опромінення спостерігали зменшення вираженості еритеми у мурчаків, ФПА крему становила 7,7 \%.

У всіх групах нанесення кремів з НЦД виявляли менший ступінь вираженості еритеми, ніж у групі контрольної патології. Найкращий результат спостерігали при застосуванні крему НЦД 0,25 \%, ФПА якого складала 43,6 \%, порівняно з ФПА 23,1 \% і 35,9 \% для кремів НЦД 0,1 \% та НЦД 0,5 \%, відповідно. У групі мурчаків, яким перед опроміненням наносили крем НЦД 0,25 \%, на одну годину експерименту ступінь вираженості еритеми не відрізнявся від такого у інтактних тварин. Еритема була менш вираженою, ніж у групі застосування крему НЦД 0,1 \% на 2-24 год досліду та у групі застосування крему НЦД 0,5 \% - на 2-8 год. Більша ефрективність крему НЦД 0,25 \% порівняно з кремом НЦД 0,5 \%, можливо, пояснюється тим, що наночастинки у більшій концентрації через втрату стабільності здатні утворювати конгломерати, які виявляють меншу фротопротекторну активність.

Таблиця 2. Динаміка розвитку еритеми в мурчаків в умовах моделі фротодинамічної травми та в групах тварин, яким перед опроміненням наносили тест-зразки кремів з НЦД ( $\mathrm{n}=10 ; \mathrm{M} \pm \mathrm{m})$

\begin{tabular}{|c|c|c|c|c|c|c|}
\hline \multirow{2}{*}{ Групи тварин } & \multicolumn{6}{|c|}{ Ступінь вираженості еритеми, бали } \\
\hline & 1 год & 2 год & 4 год & 8 год & 16 год & 24 год \\
\hline $\begin{array}{l}\text { Інтактний } \\
\text { контроль }\end{array}$ & $0,00 \pm 0,00$ & $0,00 \pm 0,00$ & $0,00 \pm 0,00$ & $0,00 \pm 0,00$ & $0,00 \pm 0,00$ & $0,00 \pm 0,00$ \\
\hline $\begin{array}{l}\text { Контрольна } \\
\text { патологія (УФ) }\end{array}$ & $2,30 \pm 0,26^{\star}$ & $2,50 \pm 0,27^{*}$ & $3,10 \pm 0,18^{*}$ & $3,50 \pm 0,17^{*}$ & $3,80 \pm 0,13^{*}$ & $3,90 \pm 0,10^{*}$ \\
\hline НЦД 0,1 \% + УФ & 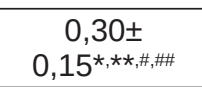 & 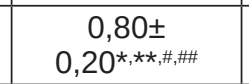 & 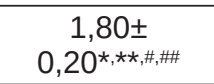 & $2,30 \pm 0,2$ & $2,70 \pm 0,21^{*, * *, \#}$ & $3,00 \pm 0,266^{*, \star *, \#}$ \\
\hline НЦД 0,25 \% + УФ & $0,10 \pm 0,10 * \star \#$ & $\begin{array}{c}0,30 \pm \\
0,15^{\star, * \star, \#, \dagger, \dagger \dagger}\end{array}$ & $\begin{array}{c}0,60 \pm \\
0,16^{\star, * \star, \#, \#,+,+\dagger \dagger}\end{array}$ & $\begin{array}{c}1,60 \pm \\
0,16^{\star, * *, \#, \# \#, \uparrow,+\dagger}\end{array}$ & $\begin{array}{c}2,10 \pm \\
0,23^{\star, \star \star, \#, \#, \uparrow}\end{array}$ & $\begin{array}{c}2,20 \pm \\
0,20^{\star, \star \star, \#, \#, \uparrow}\end{array}$ \\
\hline НЦД 0,5 \% + УФ & 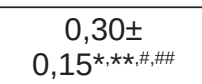 & 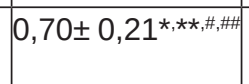 & $1,50 \pm 0,22^{\star, \star \star, \#}$ & $2,10 \pm 0,23^{\star, \star \star, \#}$ & 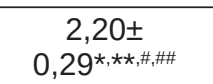 & $2,50 \pm 0,24^{\star, \star \star \star \#}$ \\
\hline ТД $3 \%+$ УФ & $0,00 \pm 0,00^{* *, \#}$ & $0,30 \pm 0,15^{*, * *, \#}$ & $1,40 \pm 0,16^{*, \star *, \#}$ & $2,30 \pm 0,21^{*, \star *, \#}$ & $2,89 \pm 0,31^{*, * *, \#}$ & $3,00 \pm 0,26^{*, * *, \#}$ \\
\hline Плацебо + УФ & $1,80 \pm 0,33^{*}$ & $2,20 \pm 0,33^{*}$ & $2,80 \pm 0,29^{*}$ & $3,30 \pm 0,15^{*}$ & $3,50 \pm 0,17^{*}$ & $3,60 \pm 0,16^{\star, \star *}$ \\
\hline
\end{tabular}

Примітки: $n$ - кількість тварин у групі; * - p < 0,05 порівняно з групою інтактного контролю; ** - $>$ < 0,05 порівняно з групою контрольної патології; \# - p < 0,05 порівняно з групою тварин, яким перед опроміненням наносили плацебо, \#\# - p < 0,05 порівняно з групою тварин, яким перед опроміненням наносили крем ТД 3 \%, † - p < 0,05 порівняно 3 групою тварин, яким перед опроміненням наносили крем НЦД 0,1\%, †† - p < 0,05 порівняно 3 групою тварин, яким перед опроміненням наносили крем НЦд 0,5\%.

ISSN 2312-0967. Pharmaceutical review. 2018. № 3 
Фармацевтична технологія, біофармація, гомеопатія Pharmaceutical technology, biopharmacy, homeopathy

У групі тварин, яким перед опроміненням наносили ресрерентний зразок - крем ТД 3 \%, фротодинамічна травма також була менш вираженою, ніж у групі контрольної патології. Через одну годину після опромінення ступінь вираженості еритеми не відрізнявся від такого у інтактних тварин. Однак за ефективністю крем ТД 3 \% поступався крему НЦД 0,25 \%. На шкірі тварин, яким наносили референтний зразок, спостерігали більшу кількість виразок, площа ураження була поширенішою. Вже через 4 год після опромінення у групі тварин, яким наносили крем НЦД 0,25\%, спостерігали на 57,1 \% нижчий ступінь вираженості еритеми, ніж у групі застосування крему ТД 3 \%. ФПА ресрерентного зразка становила 23,1\%.

Таким чином, крем НЦД 0,25 \% виявив найбільшу фотопротекторну активність порівняно 3 іншими тест-зразками кремів з НЦД за ступенем вираженості еритеми - локальної ознаки запалення, перевищуючи дію референтного зразка. На опромінених ділянках шкіри мурчаків, яким профрілактично наносили крем з НЦД, виявлено меншу кількість виразок і глибоких уражень шкірних покривів. Площа та інтенсивність фротодинамічного запального процесу, головною складовою якого є еритема, в групі тварин, яким перед опроміненням наносили крем НЦД 0,25 \%, були меншими.

Для виявлення здатності тест-зразків кремів попереджати розвиток системного запального процесу після УФ опромінення визначали їх вплив на динаміку зміни температури шкірних покривів мурчаків. У групі інтактного контролю значення показника не виходили за межі фрізіологічної норми (табл. 3). У опромінених мурчаків, починаючи з першої години експерименту, спостерігали підвищення температури шкіри як порівняно з інтактними тваринами, так і порівняно 3 вихідним значенням. Через 4 год після опромінення показник зростав на $0,35^{\circ} \mathrm{C}$.
У групі тварин, яким наносили плацебо, температура шкірних покривів протягом періоду реєстрації підвищувалася на $0,26^{\circ} \mathrm{C}$, на 4 годину була на $0,16{ }^{\circ} \mathrm{C}$ нижчою, ніж у тварин групи контрольної патології, що вказує на помірну здатність кремової основи попереджати запалення.

У групах тварин, яким перед опроміненням наносили креми з НЦД, через одну годину експозиції спостерігали зростання температури шкірних покривів, яке становило 0,28, 0,16 і 0,45 ${ }^{\circ} \mathrm{C}$ для кремів НЦД 0,1\%, НЦД 0,25 \% та НЦД 0,5\%, відповідно. Однак значення показника нормалізувалося на 2 і 4 години експерименту. Найбільш ефективними у попередженні запалення виявилися креми НЦД 0,1 \% та НЦД 0,25 \% - на 4 годину експерименту температура шкірних покривів у даних групах була, відповідно, на 0,39 і $0,35^{\circ} \mathrm{C}$ нижчою, ніж у групі контрольної патології.

Рефрерентний зразок поступався за ефрективністю кремам з НЦД. Через 4 год після опромінення температура шкірних покривів не відрізнялася від такої у тварин групи контрольної патології та була, відповідно, на 0,30, 0,26 і 0,33 ${ }^{\circ} \mathrm{C}$ вищою, ніж у групах тварин, яким наносили креми НЦД 0,1 \%, НЦД 0,25 \% та НЦД 0,5 \%. Нормалізації показника протягом періоду визначення не спостерігали, температура шкірних покривів після нанесення крему ТД 3 \% залишалася підвищеною.

Вплив тест-зразків кремів на вираженість запального процесу також оцінювали за наявністю лейкоцитозу як гематологічного маркеру реакції на УФ опромінення (табл. 4). У групах контрольної патології та нанесення плацебо спостерігали найбільш виражений лейкоцитоз - збільшення кількості лейкоцитів, відповідно, на 45,7 і 43,4 \% порівняно 3 інтактними тваринами.

У групах тварин, яким перед опроміненням наносили креми з НЦД, лейкоцитоз був менш виражений.

Таблиця 3. Динаміка зміни температури шкірних покривів у мурчаків в умовах моделі фотодинамічної травми та в групах тварин, яким перед опроміненням наносили тест-зразки кремів з НЦД (n=10; $\mathrm{M \pm m})$

\begin{tabular}{|c|c|c|c|c|}
\hline \multirow{2}{*}{ Групи тварин } & \multicolumn{4}{|c|}{ Температура шкірних покривів, ${ }^{\circ} \mathrm{C}$} \\
\hline & вихідне значення & 1 год & 2 год & 4 год \\
\hline Інтактний контроль & $36,93 \pm 0,05$ & $36,90 \pm 0,05$ & $36,93 \pm 0,05$ & $36,85 \pm 0,05$ \\
\hline Контрольна патологія (УФ) & $36,97 \pm 0,03$ & $37,82 \pm 0,05^{* \bullet}$ & $38,08 \pm 0,04^{* \cdot}$ & $37,32 \pm 0,06^{* \bullet}$ \\
\hline НЦД 0,1 \% + УФ & $36,90 \pm 0,03$ & $37,18 \pm 0,07^{\star, \star *, \#, \#, \cdot}$ & $36,97 \pm 0,06 * \star, \#, \# \#$ & $36,93 \pm 0,05^{\star \star, \#, \# \#}$ \\
\hline НЦД 0,25 \% + УФ & $36,92 \pm 0,04$ & $37,08 \pm 0,07^{\star, \star \star, \#, \# \#,+十, \bullet}$ & $36,99 \pm 0,08^{\star \star, \#, \# \#}$ & $36,97 \pm 0,06^{\star \star, \#, \# \#}$ \\
\hline НЦД 0,5 \% + УФ & $36,92 \pm 0,05$ & $37,37 \pm 0,05^{\star, * *, \#, \cdot}$ & $37,05 \pm 0,08^{\star \star, \#, \# \#}$ & $36,90 \pm 0,07^{\star \star, \#, \# \#}$ \\
\hline ТД $3 \%+$ УФ & $36,91 \pm 0,04$ & $37,38 \pm 0,07^{\star, * \star \cdot} \cdot$ & $37,53 \pm 0,06^{\star, \star *, \cdot}$ & $37,23 \pm 0,08^{*} \cdot$ \\
\hline Плацебо + УФ & $36,90 \pm 0,03$ & $37,50 \pm 0,04^{*, * * \cdot}$ & $37,57 \pm 0,06^{*, * *, \cdot}$ & $37,16 \pm 0,04^{*, \star *, \cdot}$ \\
\hline
\end{tabular}

Примітки: $\mathrm{n}$ - кількість тварин у групі; * - p < 0,05 порівняно з групою інтактного контролю; ** - p < 0,05 порівняно 3 групою контрольної патології; \# - p < 0,05 порівняно з групою тварин, яким перед опроміненням наносили плацебо, \#\# - p < 0,05 порівняно з групою тварин, яким перед опроміненням наносили крем ТД 3\%, †† - p < 0,05 порівняно $з$ групою тварин, яким перед опроміненням наносили крем НЦД 0,5 \%, •-p < 0,05 порівняно з вихідним значенням.

ISSN 2312-0967. Фармацевтичний часопис. 2018. № 3 
Фармацевтична технологія, біофармація, гомеопатія Pharmaceutical technology, biopharmacy, homeopathy

Таблиця 4. Кількість лейкоцитів у периферичній крові мурчаків в умовах моделі фротодинамічної травми та в групах тварин, яким перед опроміненням наносили тест-зразки кремів з НЦД (n=10; $\mathrm{M} \pm \mathrm{m})$

\begin{tabular}{|c|c|c|}
\hline \multirow{2}{*}{ Групи тварин } & \multicolumn{2}{|c|}{ Кількість лейкоцитів у крові, 10\%/л } \\
\hline & вихідне значення & 24 год \\
\hline Інтактний контроль & $11,00 \pm 0,49$ & $11,05 \pm 0,46$ \\
\hline Контрольна патологія (УФ) & $11,15 \pm 0,43$ & $16,10 \pm 0,31^{*, \cdot}$ \\
\hline НЦД 0,1 \% + УФ & $11,45 \pm 0,43$ & $14,45 \pm 0,22^{*, * *, \#, \bullet}$ \\
\hline НЦД 0,25 \% + УФ & $11,25 \pm 0,40$ & $13,30 \pm 0,40^{*, \star *, \#, \#,+, \bullet}$ \\
\hline НЦД 0,5 \% + УФ & $10,85 \pm 0,37$ & 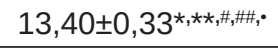 \\
\hline ТД $3 \%+$ УФ & $11,30 \pm 0,36$ & $14,55 \pm 0,42^{\star, \star *, \#, \bullet}$ \\
\hline Плацебо + УФ & $11,70 \pm 0,53$ & $15,85 \pm 0,47^{*, \cdot}$ \\
\hline
\end{tabular}

Примітки: $\mathrm{n}$ - кількість тварин у групі; * - p < 0,05 порівняно з групою інтактного контролю; ** - p < 0,05 порівняно 3 групою контрольної патології; \# - p < 0,05 порівняно з групою тварин, яким перед опроміненням наносили плацебо, \#\# - p < 0,05 порівняно з групою тварин, яким перед опроміненням наносили крем ТД 3\%, † - p<0,05 порівняно з групою тварин, яким перед опроміненням наносили крем НЦД 0,1\%, •-p < 0,05 порівняно з вихідним значенням.

Найбільш ефективними виявилися креми НЦД 0,25\% та НЦД 0,5 \% - кількість лейкоцитів у крові мурчаків була, відповідно, на 17,4 \% і 16,8 \% меншою, ніж у групі контрольної патології. За зазначеним показником крем НЦД 0,1 \% поступився крему НЦД $0,25 \%$ на $8,0 \%$.

Референтний препарат за здатністю попереджати запалення менш ефективний, ніж креми НЦД 0,25 \% та НЦД 0,5 \% - лейкоцитоз у групі застосування крему ТД 3 \% був, відповідно, на 8,6 \% і 7,9 \% більш виражений.

Гістамін є маркером ранньої фрази запалення, що вивільняється з базофрілів та опасистих клітин внаслідок їх деструкції. щодо вмісту гістаміну в крові мур- чаків, даний показник був найвищим у групі контрольної патології та застосування плацебо, тоді як у групі нанесення крему НЦД 0,25\% - не відрізнявся від такого у інтактних тварин (табл. 5). Креми НЦД 0,1\% та НЦД 0,5 \% дещо поступалися за ефективністю - у мурчаків спостерігали підвищений вміст гістаміну в крові, але на 38,5 \% і 35,4 \% менший, ніж у групі контрольної патології.

Крем ТД 3 \% за досліджуваним показником виявився не менш ефективним, ніж крем НЦД 0,25 \%. Статистично значущих відмінностей між групами тварин, яким перед опроміненням наносили дані тестзразки, не спостерігали.

Таблиця 5. Вміст гістаміну в крові мурчаків в умовах моделі фротодинамічної травми та в групах тварин, яким перед опроміненням наносили тест-зразки кремів з НЦД, через одну годину після опромінення $(n=10 ; M \pm m)$

\begin{tabular}{|l|c|}
\hline \multicolumn{1}{|c|}{ Групи тварин } & Вміст гістаміну в крові, г/л \\
\hline Інтактний контроль & $0,050 \pm 0,002$ \\
\hline Контрольна патологія (УФ) & $0,096 \pm 0,003^{*}$ \\
\hline НЦД 0,1\%+УФ & $0,059 \pm 0,002^{\star, * *, \#}$ \\
\hline НЦД 0,25\%+ УФ & $0,055 \pm 0,001^{\star *, \#}$ \\
\hline НЦД 0,5 \% + УФ & $0,062 \pm 0,002^{\star, * *, \#, \#}$ \\
\hline ТД 3\% + УФ & $0,053 \pm 0,001^{\star *, \#}$ \\
\hline Плацебо + УФ & $0,093 \pm 0,003^{*}$ \\
\hline
\end{tabular}

Примітки: $\mathrm{n}$ - кількість тварин у групі; * - p < 0,05 порівняно з групою інтактного контролю; ** - p < 0,05 порівняно 3 групою контрольної патології; \# - p < 0,05 порівняно з групою тварин, яким перед опроміненням наносили плацебо, \#\# - p < 0,05 порівняно з групою тварин, яким перед опроміненням наносили крем ТД 3 \%.

Висновки. 1. Профрілактичне нанесення кремів 3 НЦД перед УФ опроміненням шкіри зменшувало прояви фротодинамічної травми у мурчаків. За фротопротекторною активністю крем НЦД 0,25 \% виявився найбільш ефрективним (ФПА - 43,6 \% порівняно 3 ФПА 23,1 \% і 35,9 \% для кремів НЦД 0,1 \% та НЦД 0,5 \%, відповідно). У тварин з групи нанесення дано- го зразка спостерігали меншу вираженість еритеми - меншу кількість виразок і глибоких виразкових уражень шкірних покривів.

2. Застосування кремів з НЦД здатне попередити розвиток системного запального процесу у мурчаків. Нашкірне нанесення крему НЦД 0,25 \% сприяло найменшому (на $0,16{ }^{\circ} \mathrm{C}$ ), порівняно 3 іншими тест-

ISSN 2312-0967. Pharmaceutical review. 2018. № 3 
Фармацевтична технологія, біофармація, гомеопатія Pharmaceutical technology, biopharmacy, homeopathy

зразками, підвищенню температури шкірних покривів через одну годину після опромінення. Через 4 год експозиції температура нормалізувалася у всіх групах нанесення кремів з НЦД.

3. У групах тварин, яким перед опроміненням наносили креми НЦД 0,25 \% та НЦД 0,5 \%, спостерігали найменш виражений лейкоцитоз - кількість лейкоцитів у крові мурчаків була, відповідно, на 17,4 \% і 16,8 \% нижчою, ніж у групі контрольної патології. За вмістом гістаміну в крові найкращий результат продемонстрував крем НЦД 0,25 \% - у мурчаків даної групи зазначений показник не відрізнявся від такого у інтактних тварин, тоді як у інших групах застосування кремів з НЦД спостерігали підвищені значення даного показника.

4. Крем НЦД 0,25 \% перевищив за есрективністю рефрерентний зразок. Вже через 4 год після опромінення у групі тварин, яким наносили крем НЦД 0,25 \%, спостерігали на 57,1 \% нижчий ступінь вираженості еритеми, ніж у групі застосування крему ТД 3 \%, площа ураження та кількість виразок були меншими. ФПА референтного зразка становила 23,1%. Через 4 год після опромінення температура шкірних покривів у групі застосування ресрерентного зразка була на 0,26 ${ }^{\circ} \mathrm{C}$ вищою, ніж у групі тварин, яким наносили крем НЦД 0,25 \%. Крім того, у групі нанесення крему ТД 3 \% спостерігали на 8,6 \% більш виражений, порівняно з групою застосування крему НЦД 0,25 \%, лейкоцитоз.

5. За сукупністю досліджених показників крем НЦД 0,25 \% визнаний зразком-лідером та рекомендований для розробки остаточного складу лікарської фрорми та подальшого поглибленого фрармакологічного вивчення.

\title{
ВЫБОР ОПТИМАЛЬНОГО СОСТАВА КРЕМА С НАНОЧАСТИЦАМИ ЦЕРИЯ ДИОКСИДА
}

\author{
А. В. Зайченко ${ }^{1}$, О. А. Покотило모 Д. В. Литкин ${ }^{2}$ \\ Национальный медицинский университет имени А. А. Богомольца ${ }^{1}$, Киев \\ Национальный фрармацевтический университет², Харьков \\ oksana.pokotulo@gmail.com
}

Цель работы. Скрининговое исследование активности тест-образцов кремов с наночастицами диоксида церия (НДЦ) на модели фотодинамического воспаления у морских свинок с выявлением образца-лидера с оптимальным содержанием НДЦ в составе лекарственной фрормы для дальнейшего углубленного фрармакологического изучения крема.

Материалы и методы. Стандартизированные НДЦ размером 6-15 нм синтезированы сотрудниками ООО «НаноМедТех», тест-образцы кремов разработаны в НТК "Институт монокристаллов" НАН Украины. Фотодинамическую травму у морских свинок вызывали УФ облучателем с помощью ртутно-кварцевой лампы. Кремы наносили просилактически в дозе 2 мг/ $\mathrm{cm}^{2}$. Степень выраженности эритемы - главного проявления воспалительной реакции - оценивали по колориметрической шкале С. В. Суворова в динамике. По этому показателю рассчитывали фротопротекторную активность (ФПА). Способность кремов предотвращать воспалительный процесс определяли по изменению температуры кожных покровов, количества лейкоцитов и содержания гистамина в крови морских свинок.

Результаты и обсуждение. По совокупности исследованных показателей крем с 0,25 \% НДЦ проявил наивысшую фрармакологическую активность: ФПА была наибольшей среди всех тест-образцов и составляла 43,6 \%. Однократное нанесение крема способствовало нормализации температуры кожи и содержания гистамина в крови, количество лейкоцитов было на 17,4 \% меньшим, чем в группе контрольной патологии.

Выводы. По результатам скрининговыхисследований крем с 0,25\% НДЦпризнан образцом-лидером и рекомендован как окончательный состав лекарственной формы для дальнейшего углубленного фрармакологического изучения.

Ключевые слова: наночастицы церия диоксида; фоотопротекторная активность; фротодинамическая травма; скрининг; морские свинки

\section{THE SEARCH FOR THE OPTIMAL COMPOSITION OF THE CREAM WITH CERIUM DIOXIDE NANOPARTICLES}

\section{G. V. Zaychenko' , O. A. Pokotylo ${ }^{1}$, D. V. Lytkin ${ }^{2}$}

Bohomolets National Medical University ${ }^{1}$, Kyiv

National University of Pharmacy², Kharkiv

oksana.pokotulo@gmail.com

The aim of the work. The screening study of the action of the test samples of creams with cerium dioxide nanoparticles $(C D N)$ on the model of photodynamic injury in guinea pigs with determination of the lead-sample with optimal CDN contents in the formulation for further in-depth pharmacological study of the cream.

ISSN 2312-0967. Фармацевтичний часопис. 2018. № 3 
Materials and Methods. Standardized CDN of 6-15 nm in size were synthesized in TOV 'NanoMedTech', the test samples of creams were developed in SSI 'Institute for Single Crystals' of NAS of Ukraine. Photodynamic injury was induced by UV emitter. The creams were applied preventively in the dose of $2 \mathrm{mg} / \mathrm{cm}^{2}$. The degree of erythema intensity as the main inflammation marker was evaluated in dynamics according to S. V. Suvorov colorimetric scale, the photoprotective action (PPA) was measured then. An ability of the creams to prevent an inflammatory process was determined by the changes in skin temperature, blood leukocyte count, and blood histamine level.

Results and Discussion. The CDN $0.25 \%$ cream showed the highest photoprotective action according to the studied indices: PPA was the highest among all the test samples and comprised $43.6 \%$. A single application of the cream lead to normalization of skin temperature and blood histamine level, leukocytosis was $17.4 \%$ less pronounced than in radiationexposed control animals.

Conclusion. According to the screening results, the CDN $0.25 \%$ cream was proved to be the lead-sample and was recommended as an ultimate composition of the formulation for further in-depth pharmacological study.

Key words: cerium dioxide nanoparticles; photoprotective action; photodynamic injury; screening; guinea pigs.

\section{Список літератури}

1. Maresca V. Skin phototype: a new perspective / V. Maresca, E. Flori, M. Picardo // Pigment Cell Melanoma Res. - 2015. - Vol. 28, No. 4. - P. 378-389.

2. Non melanoma skin cancer pathogenesis overview / D. Didona, G. Paolino, U. Bottoni [et al.] // Biomedicines. 2018. - Vol. 6, No. 1. - P. E6.

3. Sample A. Mechanisms and prevention of UV-induced melanoma / A. Sample, Y. Y. He // Photodermatol. Photoimmunol. Photomed. - 2018. - Vol. 34, No. 1. - P. 13-24.

4. A review of critical factors for assessing the dermal absorption of metal oxide nanoparticles from sunscreens applied to humans, and a research strategy to address current deficiencies / B. Gulson, M. J. McCall, D. M. Bowman [et al.] // Arch. Toxicol. - 2015. - Vol. 89, No. 11. - P. 1909-1930. 5 . ROS-mediated genotoxicity induced by titanium dioxide nanoparticles in human epidermal cells / R. K. Shukla, Y. Sharma, A. K. Pandey [et al.] // Toxicol. In Vitro. - 2011. - Vol. 25, No. 1. - P. 231-241.

6. Дослідження гострої токсичності крему 3 наночастинками діоксиду церію / В. С. Єфанов, Г. В. Зайченко, Н. С. Нікітіна, О. А. Покотило // Тези доповідей $\mathrm{V}$ національного з'їзду фармакологів України, м. Запоріжжя, 18-20 жовтня 2017 р. - Запоріжжя, 2017. - C. 43.

7. Pokotylo O. A. The study of subchronic toxicity of the cream with cerium dioxide nanoparticles / O. A. Pokotylo, N. S. Nikitina // Topical Issues of New Drugs Development : abstracts of XXV International Scientific and Practical Conference of Young Scientists and Students, Kharkiv, April
18-20, 2018. - Kharkiv: NFaU Publishing House, 2018. P. 335-336.

8. Recent advances (2010-2015) in studies of cerium oxide nanoparticles' health effects / Y. Li, P. Li, H. Yu [et al.] // Environ. Toxicol. Pharmacol. - 2016. - Vol. 44. - P. 25-29. 9. Стефранов А. В. Биоскрининг. Лекарственные средства / А. В. Стефранов. - К. : Авиценна, 1998. - 189 с.

10. Suvorov S. V. Quantitative evaluation of erythema of the skin / S. V. Suvorov, E. B. Rabkin, V. I. Chernyshova // Bull. Exp. Biol. Med. - 1977. - Vol. 83. - P. 284.

11. Клиническая лабораторная диагностика: методы исследования : учебное пособие ; под ред. И. А. Зупанца. - [3-е изд., доп. и перераб.]. - Харьков : Золотые страницы, 2005. - 200 с.

12. Mechanisms of photoaging and cutaneous photocarcinogenesis, and photoprotective strategies with phytochemicals / R. Bosch, N. Philips, J. A. Suarez-Perez [et al.] // Antioxidants (Basel). - 2015. - Vol. 4, No. 2. - P. 248-268. 13. Pasparakis $M$. Mechanisms regulating skin immunity and inflammation / M. Pasparakis, I. Haase, F. O. Nestle // Nat. Rev. Immunol. - 2014. - Vol. 14, No. 5. - P. 289-301. 14. Патологическая фризиология : учебник / [Н. Н. Зайко, Ю. В. Быць, А. В. Атаман и др.]. - [4-е изд.]. - Москва : МЕДпресс-инорорм, 2007. - 640 с.

15. Климкина Н. В. Колориметрический метод определения гистамина в крови и органах лабораторных животных / Н. В. Климкина, С. И. Плитман // Биохимические методы исследования в гигиене. Москва : Медицина, 1973. - С. 87-91.

\section{References}

1. Maresca V, Flori E, Picardo M. Skin phototype: a new perspective. Pigment Cell Melanoma Res. 2015;28(4): 3789. Available from: http://dx.doi.org/10.1111/pcmr.12365 [Accessed July 2018]

2. Didona D, Paolino G, Bottoni U, Cantisani C. Non melanoma skin cancer pathogenesis overview. Biomedicines. 2018;6(1): E6. Available from: http://dx.doi.org/10.3390/ biomedicines6010006 [Accessed July 2018]

3. Sample A, He YY. Mechanisms and prevention of UVinduced melanoma. Photodermatol Photoimmunol Pho-

tomed. 2018;34(1): 13-24. Available from: http://dx.doi. org/10.1111/phpp.12329 [Accessed July 2018]

4. Gulson B, McCall MJ, Bowman DM, Pinheiro T. A review of critical factors for assessing the dermal absorption of metal oxide nanoparticles from sunscreens applied to humans, and a research strategy to address current deficiencies. Arch Toxicol. 2015;89(11): 1909-30. Available from: http://dx.doi.org/10.1007/s00204-015-1564-z [Accessed July 2018]

5. Shukla RK, Sharma V, Pandey AK, Singh S, Sultana S,

ISSN 2312-0967. Pharmaceutical review. 2018. № 3 
Фармацевтична технологія, біофармація, гомеопатія Pharmaceutical technology, biopharmacy, homeopathy

Dhawan A. ROS-mediated genotoxicity induced by titanium dioxide nanoparticles in human epidermal cells. Toxico In Vitro. 2011;25(1): 231-41. Available from: http://dx.doi. org/10.1016/j.tiv.2010.11.008 [Accessed July 2018]

6. lefanov VS, Zaychenko GV, Nikitina NS, Pokotylo OA. Дослідження гострої токсичності крему 3 наночастинками діоксиду церію [The study of acute toxicity of the cream with cerium dioxide nanoparticles]. In: V національницй з"їзд фрармакологів України [V National Congress of Pharmacologists of Ukraine] 2017 Oct 18-20; Zaporizhzhia (Ukraine); 2017. p. 43. Ukrainian.

7. Pokotylo OA, Nikitina NS. The study of subchronic toxicity of the cream with cerium dioxide nanoparticles. In: Topical Issues of New Drugs Development; XXV Internationa Scientific and Practical Conference of Young Scientists and Students 2018 Apr 18-20; Kharkiv (Ukraine): Vydavnytstvo NFaU; 2018. p. 335-6.

8. Li Y, Li P, Yu H, Bian Y. Recent advances (2010-2015) in studies of cerium oxide nanoparticles' health effects. Environ Toxicol Pharmacol. 2016;44: 25-9. Available from: http://dx.doi.org/10.1016/j.etap.2016.04.004 [Accessed July 2018]

9. Stefanov AV. Bioskrining. Lekarstvennye sredstva [Bioscreening. Drugs]. Kiev: Avitsenna; 1998. Russian.

10. Suvorov SV, Rabkin EB, Chernyshova VI. Quantita- tive evaluation of erythema of the skin. Bull Exp Biol Med. 1977;83: 284. Available from: http://dx.doi.org/10.1007/ BF00799448 [Accessed July 2018]

11. Zupanets IA. Klinicheskaia laboratornaia diagnostika: metody issledovania [Clinical laboratory diagnostics: research design]. Kharkov: Zolotye Stranitsy; 2005. Russian. 12. Bosch R, Philips N, Suarez-Perez JA, Juarranz A, Devmurari A, Chalensouk-Khaosaat J, et al. Mechanisms of photoaging and cutaneous photocarcinogenesis, and photoprotective strategies with phytochemicals. Antioxidants (Basel). 2015;4(2): 248-68. Available from: http:// dx.doi.org/10.3390/antiox4020248 [Accessed July 2018] 13. Pasparakis M, Haase I, Nestle FO. Mechanisms regulating skin immunity and inflammation. Nat Rev Immunol. 2014;14(5): 289-301. Available from: http://dx.doi. org/10.1038/nri3646 [Accessed July 2018]

14. Zaiko NN, Byts YuV. Patologicheskaia fiziologia [Pathological physiology]. Moskva: MEDpress-inform; 2007. Russian.

15. Klimkina NV, Plitman SI. Колориметрический метод определения гистамина в крови и органах лабораторных животных [Colorimetric method of determination of histamine in blood and organs of laboratory animals]. In: Биохимические методы исследования в гигиене [Biоchemical research design in hygiene]. Moscow: Meditsina; 1973. Russian. 